\title{
Effect of Major Macroeconomic Determinants on the Progress of Pakistan
}

\author{
Rabia Najaf*, Khakan Najaf \\ *Department of Accounting \& Finance, University of Lahore, Islamabad Campus \\ *rabianajaf@hotmail.com
}

\begin{abstract}
After studying all of the papers, we have considered that stock market of all the countries known as the predictor of economy. Future economic activates can be changes with the change in the economic activities. From the last few decades, most of the observers criticized the stock exchange of Pakistan because it is not depend upon on the true fundamentals. From the last few decades, it is seen that stock market was decline on the different occasions. The vital role of our study is that to explore the impact of stock exchange on the economy of Pakistan. We are also explaining those variables, which have influences on the stock exchange of Pakistan. The basic purpose of this study is to explain the stock exchange ability to predict about the economy position of Pakistan. We have taken the stock prices as the dependent variable and import and export goods and services as the independent variables. We used the regression analysis for testing the hypothesis. We have collected the data from 2006 -2010.There is a lot of stock exchange, which are working as the predictor of the Pakistan but our focus is Karachi stock exchange, which is known as the oldest and largest stock exchange of Pakistan. Our results suggested that there is no association between stock market and changes of the stock prices.
\end{abstract}

Keywords: Karachi stock exchange, predictor, import services, export services, stock prices

\section{INTRODUCTION}

Different observers believe that stock market is the known as the barometer of the stock market. Some scholars have been studies that it is also known as the predictor of the economy. Many studies have proved that future recession is due to decrease in the stock prices. On the other side, increase in the stock prices are reflect the growth, which proved that stock market is the really act as the indicator. Demand is another relationship which has impacted on the stock prices. This impact can be generated, when stock prices decline. If the decline will significant then there will strong impact on the financial position. Such types of investors might be small investors. These investors invest in the stock exchange for short time of period. First, they losing money they will be afraid for further investment. This type of behavior will lead to decrease the consumer prices. According to Fazal (2001) cause of changes in the stock prices may cause of changes in the macroeconomic variables. High stock exchange may cause to stimulate the investment spending by the issuing the IPO. Decreasing in the stock prices have impacted on the firm s ability. Therefore, investors do not invest in the stock market in the condition of uncertainty. This is the main issue that investors do not invest in the stock market due to bad performance. According to Henry (2002) suggested that stock market is the best way for prediction. He showed that stock market has also influenced the investors way of thinking.AS discussed in the previous study stock prices always reflect the economic conditions. According to Ferreira (2007) growth in financial market increases the efforts of financial institutions. Karachi stock exchange was decline from the last few decades, and indicates the condition of recession. Bad news is known as the one of vital psychological factor, which always discourages the investors for the investment in the stock exchange. Some investors are risk taker; they want to take risk for short time of periods. Most of the study has been observed the association between stock prices and some variables like GDP, GNP, Inflation and unemployment. This paper is distinctive in a way that impact stock prices on import and exports services this is the very common issue to know about the role of Karachi stock exchange in the import and export of Pakistan .It is seen that various bad rumors have influenced on the stock prices. Most of the times, it is seen that due to horrible news investors do not invest in the Karachi stock exchange. Most of the time stock market of the Pakistan predicts very well about the future of the economy and it is also seen that decrease in the stock prices can cause the 
recession. In 2005, crash down of the stock market had not hit the economic variables. A huge study has been done on the topic of Karachi stock exchange .Karachi stock exchange was first stock exchange of Pakistan. It is known as the oldest and largest stock exchange of Pakistan. Some scholars have explained Karachi stock exchange such a way that stock exchange a place where traders exchange their securities. Stock exchange is the backbone for every country. Stock exchange has the vital role for the development of the healthy economy. In the stock exchange, there are different investors; one investors take decision on the previous information and $2^{\text {nd }}$ take decision by applying the different techniques and skills. Demand and supply is also helpful to take decision about the investment. Stock exchange is also act as the bridge between investors and borrowers. Different approaches have approved that stock prices change due to political behavior.

\section{IMPORT OF PAKISTAN With Major COUNTRIES}

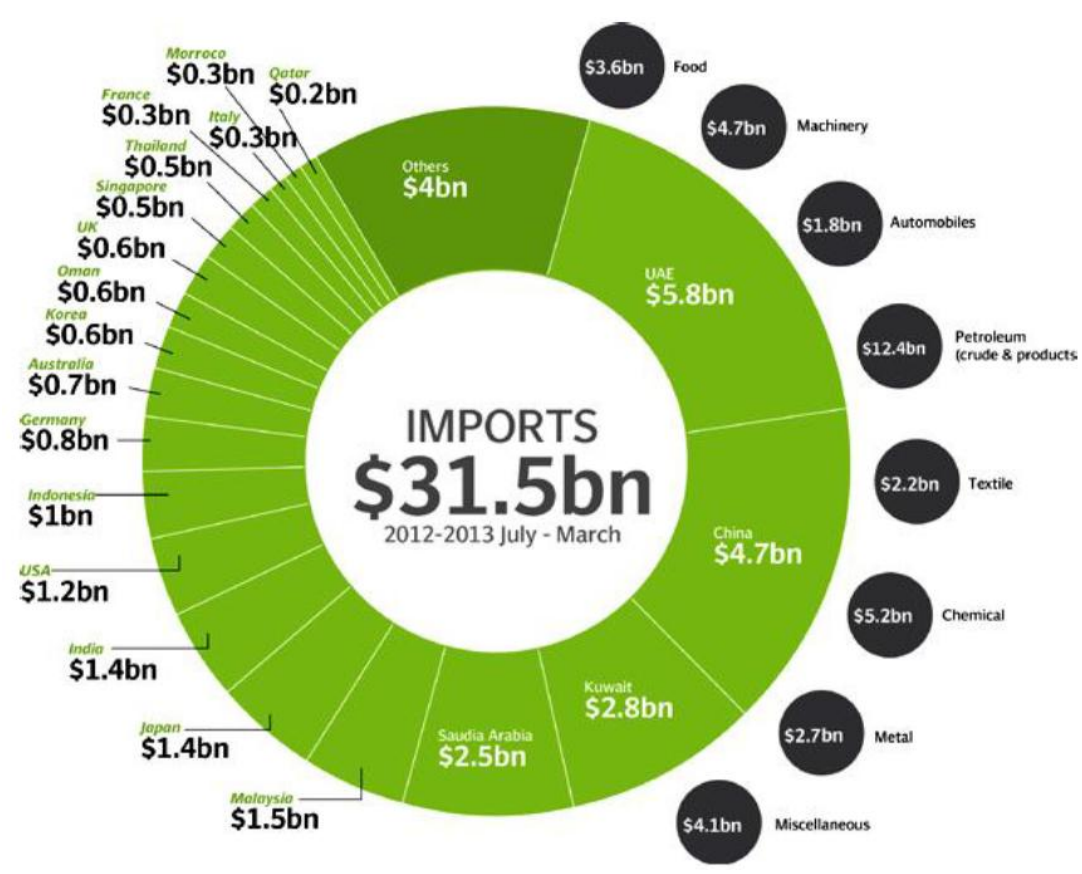

\section{Export of Pakistan With Major Countries}

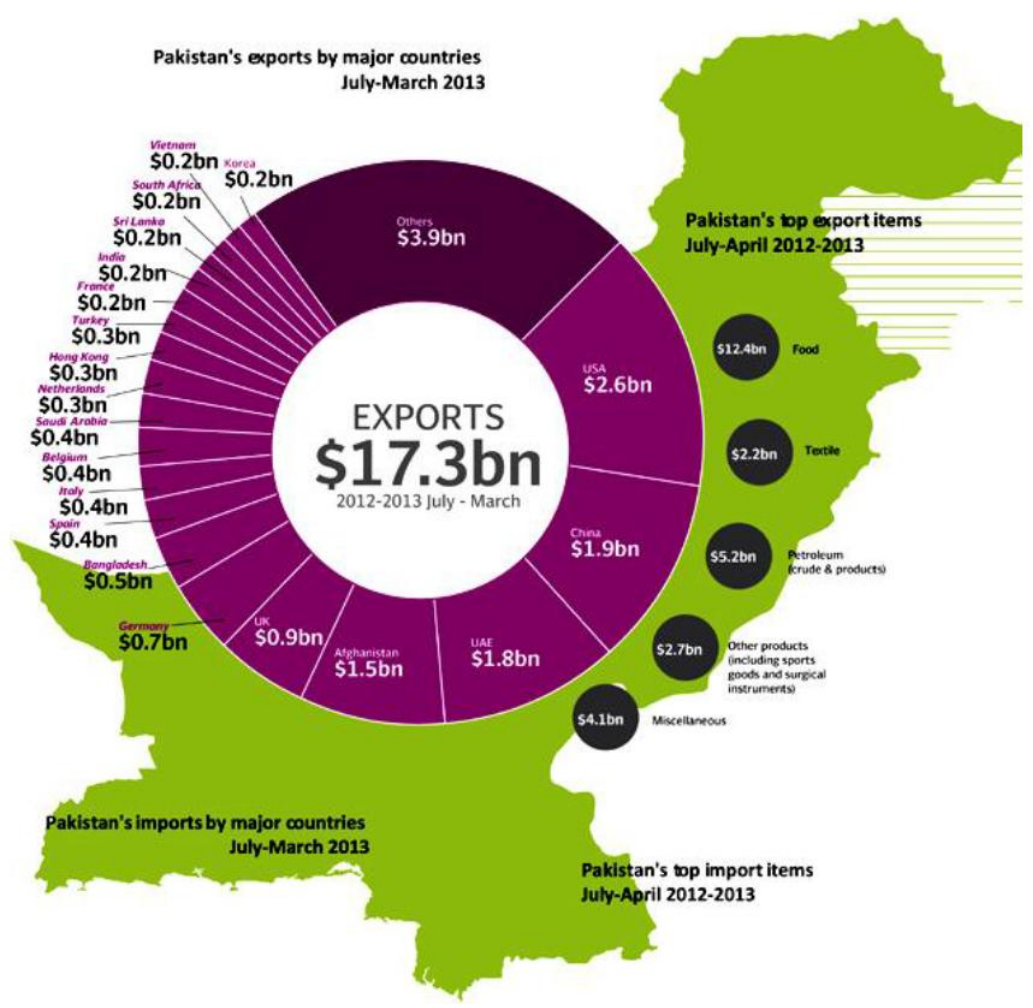


Present Political Scenario of Jammu and Kashmir and the Role of Current Collation Government of P.D.P and B.J.P

Table I. Pakistan's Annual Basic Stock Market Indicators: Karachi Stock Exchange (Kse 100)

\begin{tabular}{|l|l|l|l|l|l|l|l|l|}
\hline 0 & 1 & 2 & 3 & 4 & 5 & 6 & 7 & 8 \\
\hline Years & N & MC & ST & TV & TOR & SBGI & KSE 100 & ROR \\
\hline & & (Bill Rs.) & (Bill No.) & (Bill Rs.) & (Bill Rs.) & & & $\%$ \\
\hline FY 1990 & 488 & 61.8 & 0.4 & 4.99 & 8.8 & 308.6 & - & \\
\hline FY 1991 & $\mathbf{5 4 3}$ & $\mathbf{1 8 0 . 3}$ & $\mathbf{0 . 5}$ & $\mathbf{1 5 . 2 5}$ & $\mathbf{1 2 . 7}$ & $\mathbf{7 1 8 . 3}$ & $\mathbf{1 6 7 2 . 9}$ & $+\mathbf{+ 1 0 3 . 2}$ \\
\hline FY 1992 & 627 & 204.8 & 0.7 & 24.45 & 12.8 & 637.6 & 1243.6 & -25.8 \\
\hline FY 1993 & 654 & 347.9 & 1.4 & 51.59 & 18.8 & 907.9 & 2164.4 & +74.1 \\
\hline FY 1994 & 725 & 377.4 & 1.9 & 97.48 & 26.8 & 901.3 & 2049.2 & -5.5 \\
\hline FY 1995 & 766 & 317.8 & 3.2 & 101.46 & 29.3 & 737.2 & 1497.9 & -26.8 \\
\hline FY 1996 & 783 & 426.5 & 6.7 & 218.22 & 58.7 & 535.2 & 1339.8 & -10.6 \\
\hline FY 1997 & 782 & 483.7 & 13.4 & 471.35 & 103.8 & 536.7 & 1753.7 & +30.8 \\
\hline FY 1998 & 774 & 265.7 & 18.6 & 427.45 & 114.4 & 375.8 & 945.3 & -46.2 \\
\hline FY 1999 & 766 & 361.4 & 31.4 & 1081.98 & 345.3 & 460.9 & 1408.8 & +49.2 \\
\hline FY 2000 & 763 & 379.2 & 46.3 & 1760.08 & 475.6 & 487.4 & 1507.7 & +7.1 \\
\hline FY 2001 & 748 & 296.2 & 19.9 & 765.62 & 226.9 & $\mathbf{5 7 8 . 5} * *$ & 1273.2 & -15.7 \\
\hline FY 2002 & 713 & 595.3 & 37.8 & 154.98 & 346.3 & $\mathbf{5 1 9 . 8}$ & 2701.6 & +112.3 \\
\hline FY 2003 & 702 & 951.5 & 76.5 & 3846.39 & 497.5 & $\mathbf{9 9 8 . 6}$ & 4471.7 & +65.6 \\
\hline FY 2004 & 662 & 1357.6 & 98 & - & 386.8 & $\mathbf{1 5 7 5 . 5}$ & 6218.5 & +39.2 \\
\hline FY 2005 & 658 & 2013.3 & 88.4 & - & 351.8 & $\mathbf{1 7 6 7 . 8}$ & 7450.2 & +19.9 \\
\hline FY 2006 & 657 & 2802 & 104.8 & - & 319.7 & $\mathbf{2 0 8 0 . 7}$ & 9989.5 & +34.2 \\
\hline FY 2007 & 656 & 3781.3 & 33.6 & - & 208.5 & $\mathbf{2 6 6 7 . 7}$ & 12,275 & +22.8 \\
\hline Mean & & & 32.28 & $\mathbf{6 4 4 . 3 7 8}$ & 196.87 & 933.04 & 3528 & 25.16 \\
\hline SD & & & 35.87 & $\mathbf{1 0 5 0 . 1 5}$ & 174.07 & 657.48 & 3425 & 45.52 \\
\hline
\end{tabular}

** The Base Index in the FY 2001 was changed back to 100 points.

\section{Problem Statement}

Impact of export and import on the stock prices of Karachi stock exchange.

\section{Objectives}

1. What are the relationships between stock prices and exports services of Pakistan?

2. What are the relationship between export services and stock prices?

\section{THEORETICAL FRAME WORK}

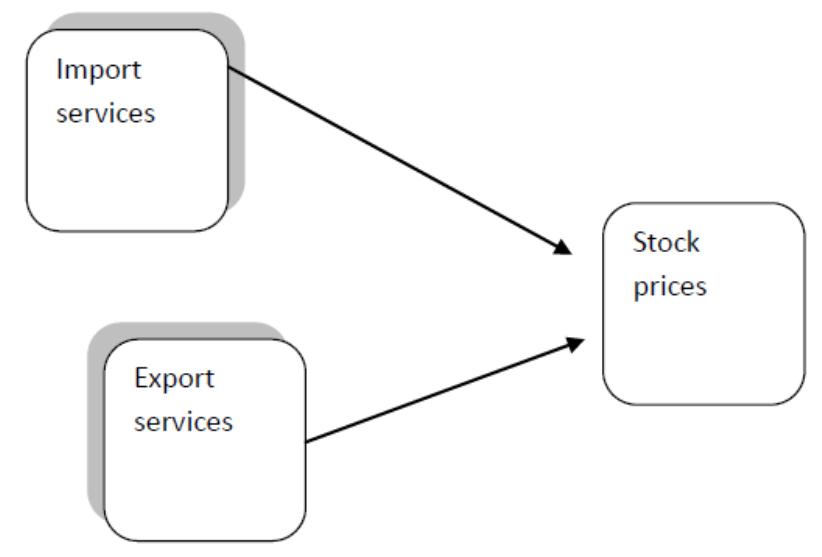

\section{LITERATURE REVIEW}

Atesoglu. H. S, Examined the impact of macroeconomic volatility on the stock prices of Bangladesh. For this purpose, they used the monthly data and analyzed the impact of CPI on the stock prices. They utilized the data of 1990 -2004.they had utilized the GARCH model and found that there is relationship between them. There is found negative relationship between them and suggested that there is need to control the inflation rate [1].

Ando and Modigliani Observed the impact of macroeconomic volatility on the stock prices of India. For this purpose, they used the monthly data and analyzed the impact of exchange rate on the stock 
prices. They utilized the data of 1991 -2005.they had utilized the VECM model and found that there is relationship between them. There is found positive relationship between them and suggested that there is need to control the exchange rate [2].

Braun and Borja, Analyzed the impact of macroeconomic volatility on the stock prices of Pakistan. For this purpose, they used the monthly data and analyzed the impact of GDP on the stock prices. They utilized the data of 1994 -2006.they had utilized the VAR model and found that there is relationship between them. There is found positive relationship between them and suggested that there is need to make policy related to the GDP [3].

Christos, F, Examined the impact of macroeconomic volatility on the stock prices of China. For this purpose, they used the monthly data and analyzed the impact of industrial production on the stock prices. They utilized the data of 1998 -2008.they had utilized the bivariate model and found that there is relationship between them. There is found positive relationship between them and suggested that there is need to make policy of industrial production [4].

Ferreira, C. Observed the impact of macroeconomic volatility on the stock prices of Pakistan. For this purpose, they used the monthly data and analyzed the impact of unemployment rate on the stock prices. They utilized the data of 1999 -2009.they had utilized the VECM model and found that there is relationship between them. There is found negative relationship between them and suggested that there is need to make policy related to the unemployment rate [5].

Fazal, H, Analyzed the impact of macroeconomic volatility on the stock prices of Japan. For this purpose, they used the monthly data and analyzed the impact of political instability on the stock prices. They utilized the data of 1990 -2010.they had utilized the unit root model and found that there is relationship between them. There is found positive relationship between them and suggested that there is need to make policy of political instability [6].

Henry, P.B, observed the impact of macroeconomic volatility on the stock prices of France. For this purpose, they used the monthly data and analyzed the impact of GDP on the stock prices. They utilized the data of 1996 -2001.they had utilized the VECM model and found that there is relationship between them. There is found positive relationship between them and suggested that there is need to make policy related to the GDP [7].

Liow, Muhammad and Huang, Examined the impact of macroeconomic volatility on the stock prices of Turkey. For this purpose, they used the monthly data and analyzed the impact of exchange rate on the stock prices. They utilized the data of 1999 -2009.they had utilized the multi regression model and found that there is relationship between them. There is found positive relationship between them and suggested that there is need to make policy related to the exchange rate [8].

Jain, P, C, and Examined the impact of macroeconomic volatility on the stock prices of Canada. For this purpose, they used the monthly data and analyzed the impact of CPI on the stock prices. They utilized the data of 1998 -2008.they had utilized the GARCH model and found that there is relationship between them. There is found negative relationship between them and suggested that there is need to control the inflation rate [9].

Levine and Sara, Analyzed the impact of macroeconomic volatility on the stock prices of USA. For this purpose, they used the monthly data and analyzed the impact of industrial production on the stock prices. They utilized the data of 1991 -2008.they had utilized the VECM model and found that there is relationship between them. There is found positive relationship between them and suggested that there is need to make policy of industrial production [10].

Levine, R. Analyzed the impact of macroeconomic volatility on the stock prices of UK. For this purpose, they used the monthly data and analyzed the impact of political instability on the stock prices. They utilized the data of 1980 -2008.they had utilized the unit root model and found that there is relationship between them. There is found positive relationship between them and suggested that there is need to make policy of political instability [11].

Lyigun and Ann, observed the impact of macroeconomic volatility on the stock prices of China. For this purpose, they used the monthly data and analyzed the impact of industrial production on the stock prices. They utilized the data of 1998 -2008.they had utilized the VAR model and found that there is relationship between them. There is found positive relationship between them and suggested that there is need to make policy of industrial production [12]. 
Levine and Sara, Examined the impact of macroeconomic volatility on the stock prices of Sri Lanka. For this purpose, they used the monthly data and analyzed the impact of CPI on the stock prices. They utilized the data of 1995-2010.they had utilized the GARCH model and found that there is relationship between them. There is found negative relationship between them and suggested that there is need to control the inflation rate [13].

Nagaishi, M., Observed the impact of macroeconomic volatility on the stock prices of Pakistan. For this purpose, they used the monthly data and analyzed the impact of unemployment rate on the stock prices. They utilized the data of 1999 -2009.they had utilized the VECM model and found that there is relationship between them. There is found negative relationship between them and suggested that there is need to make policy related to the unemployment rate [14].

Odedokun, M, O, analyzed the impact of macroeconomic volatility on the stock prices of Denmark. For this purpose, they used the monthly data and analyzed the impact of GDP on the stock prices. They utilized the data of 1990 -2009.they had utilized the VAR model and found that there is relationship between them. There is found positive relationship between them and suggested that there is need to make policy related to the GDP [15].

Park, S, observed the impact of macroeconomic volatility on the stock prices of Germany.. For this purpose, they used the monthly data and analyzed the impact of industrial production on the stock prices. They utilized the data of 1992 -2002.they had utilized the VAR model and found that there is relationship between them. There is found positive relationship between them and suggested that there is need to make policy of industrial production [16].

\section{GAPS OF THE Literature}

1) In the prior study there have been studies about the some variables impact on the stock market of Pakistan but did not discuss about the impact of export on the market.

2) In the previous study there is a lot of discussion about inflation rate, exchange rate ,GDP on the stock market but did not discuss about the impact of import on the stock previous.

3) Nobody has discussed about the proper way of prediction

4) In this study, we have analyzed that how can we predicted about the future values.

\section{Methodology}

We have used the five years data for this purpose. We collected the data from different websites. We have taken five years data.

\section{RESEARCH MODELS}

Model 1: Imports $=\alpha+\beta$ (stock prices)

Model 2: Exports $=\alpha+\beta$ (stock prices)

Model 3: $\Delta$ Stock Prices $=\alpha+$ lag_1 Stock Prices

Model 4: $\Delta$ Exports $=\alpha+\operatorname{lag} \_1$ Stock Prices

Model 5: $\Delta$ Imports $=\alpha+\operatorname{lag} \_1$ Stock Prices

We have utilized the five models, our main variables are shown imports and exports and lags are taken for the prediction of dependent variable. The basic purpose of these econometric techniques are to test the different hypothesis. Mostly, we used the co-integration to check the association between dependent and independent variables.

\section{FINDING AND INTERPRETATION OF THE RESULTS}

Vector error correction estimates

Sample (adjusted) 461 


\section{Table1}

\begin{tabular}{|c|c|c|c|}
\hline Co-integrating Eq: & \multicolumn{3}{|l|}{ CointEq1 } \\
\hline STOCKS (-1) & \multicolumn{3}{|l|}{2.000000} \\
\hline EXPORTS (-1) & \multicolumn{3}{|l|}{$\begin{array}{l}-215.1309 \\
(38.5612) \\
{[-5.03102]}\end{array}$} \\
\hline IMPORTS (-1) & \multicolumn{3}{|l|}{$\begin{array}{l}15.17036 \\
(8.40193) \\
{[2.50718]}\end{array}$} \\
\hline @TREND (1) & \multicolumn{3}{|l|}{$\begin{array}{l}631.8664 \\
(232.112) \\
{[2.49459]}\end{array}$} \\
\hline $\mathrm{C}$ & \multicolumn{3}{|l|}{140461.2} \\
\hline ERROR correction: & D (STOCKS) & D (EXPORTS) & D (IMPORTS) \\
\hline CointEq1 & $\begin{array}{l}0.026151 \\
(0.00885) \\
{[2.95758]}\end{array}$ & $\begin{array}{l}0.006628 \\
(0.00238) \\
{[2.79796]}\end{array}$ & $\begin{array}{l}-0.000691 \\
(0.00402) \\
{[-0.17213]}\end{array}$ \\
\hline
\end{tabular}

Model 1: Imports $=\alpha+\beta$ (stock prices)

Model 2: $\alpha+\beta$ (stock prices)

In these models there is need of SURE. There is positive value is present here. The value of trends and $\mathrm{t}$ are showing that there is association between them.

Model 3: $\Delta$ Stock Prices $=\alpha+\operatorname{lag} \_1$ Stock Prices

In the model no 3 there is found the significant result because value is more than 1.5 which is 2.95758.this is showing that previous value has impact on the next month stock prices.

Model 4: $\Delta$ Exports $=\alpha+\operatorname{lag} 1$ Stock Prices

We have found that exports are significant because its value is 2.79796 which is more than 1.5.it means that previous effect has influenced on the next month stock prices.

Model 5: $\Delta$ Imports $=\alpha+$ lag_1 Stock Prices

In the model no 5 there is insignificant because its value is less then 1.5.which is -0.17212.previous values is not prediction about the future. So we have rejected the h4 because its value is less then 1.5.this research is also showing that there is need of SUR due to value of trends.

\section{Conclusion}

Our results are showing that past values has showed the present fluctuation in the stock prices and exports prices can be predicted by the current fluctuation. On the other side, the past values have not impacted on the import activities. We have rejected the h4 and accepted the h2 and h3.

\section{RECOMMENDATIONS}

In this paper, we have analyzed that Karachi stock exchange is the unpredictable due to its uncertain behavior. This paper has provided the opportunity for new scholars to work on the interdependency between stick prices and different macroeconomic variables. Different reports have showed that there is less exports in Pakistan and last month s stock market is reason of changes in the next month services of goods and services.

\section{REFERENCES}

[1] Atesoglu. H. S. (2002). Stock Prices and Employment. Journal of Post Keynesian Economics. 24(3), 493-498.

[2] Ando and Modigliani. (1963). The "Life Cycle" Hypothesis of Saving: Aggregate Implication sand Tests. The American Economic Review, 53(1), 55-84.

[3] Braun and Borja. (2005). Finance and the Business Cycle: International Industry Evidence. The Journal of Finance. 60(3), 1097-1128.

[4] Christos, F. (2004). Stock Returns and Inflation in Greece. Applied econometrics and International development (AEEADE). 4(2), 55-68. 
[5] Ferreira, C. (2008). The banking sector, economic growth and European integration. Journal of economic studies. 35 (6), 512-527.

[6] Fazal, H. (2006). Stock Prices, Real Sector and the Causal Analysis. Journal of management and social science. 2, 179-185.

[7] Henry, P.B. (2002). Is Disinflation Good for the stock market? The Journal of Finance. 57(4), 1617-1648.

[8] Liow, Muhammad and Huang. (2006). Macroeconomic risk influences on the property stock market. Journal of property Investment \& Finance. 24(4), 295-323.

[9] Jain, P, C. (1988). Response of hourly stock prices and trading volume to economic news. The Journal of Business. 61(2), 219-231.

[10] Levine and Sara. (1998). Stock Markets, Banks, and Economic Growth. The American Economic Review. 88(3), 537-558.

[11] Levine, R. (1997). Financial Development and Economic Growth: Views and Agenda. Journal of Economic Literature. 35(2), 688-726.

[12] Lyigun and Ann. (2004). Financial Development and Macroeconomic Fluctuations. The Economic Journal. 114(495), 352-376.

[13] Levine and Sara. (1996). Stock Market Development and Long-Run Growth. The World Bank Economic Review. 10(2), 323-339.

[14] Nagaishi, M. (1999). Stock Market Development and Economic Growth: Dubious Relationship. Economic and Political Weekly, 34(29), 2004-2012.

[15] Odedokun, M, O. (1998). Financial intermediation and economic growth in developing Countries, Journal of Economics Studies, 25(3), 203-224.

[16] Park, S. (1997). Rationality of Negative Stock-Price Responses to Strong Economic Activity.Financial Analysts Journal, 53(5), 52-56. 